\title{
Alexander Albrecht - Suita pre klavír
}

\author{
Kristína Skatuloková
}

\section{úvod}

Alexander Albrecht patrí k prvým predstavitelom modernej slovenskej hudby. Jeho osobnost' je spätá s počiatkami formovania a budovania nových základov v slovenskej hudobnej kultúre, najmä v súvislosti s profesionalizáciou hudobných telies v medzivojnovom období. V historických kontextoch hudobného života na Slovensku bol pomerne na dlhý čas odsunutý do úzadia prúdom slovenskej národnej moderny, ktorá vstúpila s ideou orientovanou na využitie bohatstva a rozmanitosti nášho hudobného folklóru. Jeho dielo však tvorí dôležitý článok v ret’azi vývoja modernej slovenskej hudby tým, že stálo v jeho počiatočných fázach.

Alexander Albrecht pôsobil ako klavirista najmä počas svojho štúdia na Hudobnej akadémii Franza Liszta v Budapešti, neskôr ako pedagóg hry na klavíri a teórie na Hudobnej škole Cirkevného hudobného spolku sv. Martina. Hoci mal vel'mi dobré základy, aby vystupoval ako sólista a venoval sa klavírnemu umeniu, nemal tieto ambície. Bol nesmierne všestranne založeným človekom. Práve tieto jeho skladatel'ské a organizačné schopnosti, nadanie, budovatel'ské tendencie a profilácia vymykajúce sa istému „škatul'kovaniu“ jeho osobnosti, boli príčinou Albrechtovho d’alšieho životného smerovania. Svoj život okrem pedagogických, dirigentských, organizačných a publikačných činností „zasvätil“ najmä komponovaniu komorných diel, piesní, orchestrálnej, zborovej a organovej tvorby, pričom na sklonku svojho života tvoril aj inštruktívne skladby pre deti a mládež. Musíme však povedat', že aj ked'klavírnych diel skomponoval pomerne málo, klavír ako médium zohráva v Albrechtovom kompozičnom odkaze klúčovú úlohu. Vidíme to na vel'kom množstve komorných diel s klavírom, piesní so sprievodom klavíra i na niekol'kých transkripciách jeho kompozícií, z ktorých niektoré v poslednom tvorivom období upravoval do klavírnej podoby. Klavír pre neho nebol nástrojom preverovania si virtuóznych možností hry. Naopak, snažil sa hudobný nápad vložit' do skladieb so zámerom vyvolania konkrétnej expresivity. Aj napriek tomu, že skladatelov kompozičný odkaz v oblasti klavírnych diel netvorí t’ažisko jeho kompozičnej práce, je jeho neoddelitel'nou súčast’ou. O to viac si zaslúži pozornost' či už zo strany inter- 
pretov, muzikológov, všetkých priaznivcov hudby. Albrechtovo klavírne dielo má silné zastúpenie v slovenskej klavírnej literatúre.

Štúdia sa snaží priblížit skladatel’ovo klavírne dielo Suita pre klavír. Pomocou podrobnej hudobnej analýzy sa zameriava najmä na formovú, harmonickú a výrazovú stránku so špecifickým zretelom na motivicko-tematickú prácu.

\section{Suita pre klavír}

Skladatel' skomponoval Klavírnu suitu v roku 1924. Albrechtov kompozičný štýl má v tejto kompozícii vyhranený charakter. Od jeho študentskej kompozície Sonáta pre klavír Fdur sa líši práve odstránením romantických a iných tendencií, ktoré by išli v šlapajach skladatelov minulosti. Klavírnu suitu môžeme pokladat' za jedno z prvých diel, v ktorom Albrecht dospel k vlastnej osobitej štylizácii a výrazu. Skladatel’ovým zámerom bolo predostriet' nový, moderne znejúci spôsob rozoznenia klavíra. ' Štvorčastový cyklus Klavírnej suity má tanečný charakter, pripomínajúci klavírnu štylizáciu Bélu Bartóka. Časti Tanec, Humoreska, Uspávanka, Pochod prinášajú pomerne výrazné náladové kontrasty. ${ }^{2}$ Všetky štyri časti na prvý pohlad disponujú úspornostou výrazových prostriedkov, a to napriek jej technickej náročnosti. Aj virtuozita je tu v úzadí. Z hladiska formy je rozvrh cyklu tradičný. Skladatelovým zámerom bolo inovovat' či už tonálne alebo štrukturálne romantické a novoromantické dedičstvo bez akéhokolvek tonálneho negovania. Pre svoju mimoriadne odvážnu harmonickú štruktúru si kompozícia vyslúžila kritiku bratislavského publika pri svojom prvom predvedení (26. 3. 1926 - interpret Štefan Németh). Vtedajším poslucháčom bola jej odvážna hudobná reč príliš vzdialená. ${ }^{3}$ Samotný Albrecht však považoval Klavírnu suitu za jedno z prvých diel, v ktorom dosiahol samostatnejší a vyhranenejší hudobný prejav. Dokonca bol toho názoru, že najlepšie skomponovaná čast' z cyklu je Humoreska, pričom dal súhlas na jej samostatné uvádzanie. ${ }^{4}$

V nasledujúcich tabul'kách uvádzame formu Suity pre klavír:

\begin{tabular}{|l|}
\hline 1. čast' Tanec \\
\hline Sonátový rozvrh - vol'ne aplikovaná forma \\
\hline EXP - ROZ - REP - KÓDA \\
\hline Expozícia: 2 témy s kontrastným charakterom \\
Téma č. 1: „Andante con moto“ \\
Téma č. 2: „Poco più lento“ - začína sa \\
označením „a tempo“ \\
\hline Rozvedenie: práca s hlavnou témou \\
\hline $\begin{array}{l}\text { Repríza: inverzná, využíva najskôr vedlajšiu } \\
\text { myšlienku + kontrastnú myšlienku } \\
\text { (medzivetný úsek) }\end{array}$ \\
\hline „Kóda“ (malý typ): evokuje návrat \\
expozície, zastupuje element rytmicko- \\
-melodický, úsek plní funkciu reprízy \\
\hline
\end{tabular}

\begin{tabular}{|l|}
\hline 2. čast' Humoreska \\
\hline Piesňová forma s kódou \\
\hline A - B - prechodný úsek - centrálny úsek - \\
A' - KÓDA $^{\prime}$ \\
\hline $\begin{array}{l}\text { A: hlavný tematický materiál a práca } \\
\text { s motívom (mikrotektonika) }\end{array}$ \\
\hline B: kontrastný diel so zmenou charakteru \\
\hline $\begin{array}{l}\text { prechodný úsek: práca s kvintolou (využíva } \\
\text { materiál z dielu A) }\end{array}$ \\
\hline $\begin{array}{l}\text { centrálny úsek (dohra): práca s dvomi } \\
\text { kontrastnými motívmi }\end{array}$ \\
\hline $\begin{array}{l}\text { A': predstavuje reprízu s vol'ne } \\
\text { koncipovaným materiálom - v inverznej } \\
\text { podobe (hlavný motív uvedený v závere) }\end{array}$ \\
\hline $\begin{array}{l}\text { Kóda (velký typ): motivicko- tematická } \\
\text { práca s materiálom zo všetkých dielov }\end{array}$ \\
\hline
\end{tabular}




\begin{tabular}{|l|}
\hline 3. čast' Uspávanka \\
\hline Piesňová forma s kódou \\
\hline $\begin{array}{l}\text { A (+ introdukcia) - B - Repríza inverzná } \\
\left(B^{\prime}-A^{\prime}\right) \text { - KóDA }\end{array}$ \\
\hline $\begin{array}{l}\text { A: hlavná tematická plocha vrátane úvodnej } \\
\text { introdukcie (uvedenie hlavného motívu) }\end{array}$ \\
\hline B: stredný diel s kontrastnou témou \\
\hline $\begin{array}{l}B^{\prime} \text { : inverzná podoba, práca s hlavným } \\
\text { motívom v rytmickým obmenách }\end{array}$ \\
\hline$A^{\prime}$ : návrat hlavnej tematickej plochy \\
\hline $\begin{array}{l}\text { Kóda: práca s materiálom kontrastnej témy } \\
\text { + hlavným motívom }\end{array}$ \\
\hline
\end{tabular}

\begin{tabular}{|c|}
\hline 4. čast' Pochod \\
\hline Sonátové rondo (polytematické) \\
\hline $\begin{array}{l}\text { Introdukcia - A - B (+ medziveta) - C - B' } \\
A^{\prime}-C^{\prime}-A^{\prime \prime}-\text { KÓDA }\end{array}$ \\
\hline $\begin{array}{l}\text { Introdukcia: hlavná tematická plocha } \\
\text { v štylizácii pochodu } \\
\text { A: uvedenie hlavného motívu }\end{array}$ \\
\hline $\begin{array}{l}\text { B: kontrastná myšlienka č. } 1 \text { (zmena } \\
\text { rytmizácie a charakteru) + medzivetný } \\
\text { úsek }\end{array}$ \\
\hline $\begin{array}{l}\text { C: kontrastná myšlienka č. } 2 \text { v zmenenej } \\
\text { pochodovej štylizácii }\end{array}$ \\
\hline $\begin{array}{l}\text { B': návrat kontrastnej myšlienky č. } 1 \\
\text { v modifikácii }\end{array}$ \\
\hline $\begin{array}{l}\text { A': návrat hlavnej témy z introdukcie } \\
\text { v modifikácii }\end{array}$ \\
\hline $\begin{array}{l}\text { C': návrat kontrastnej myšlienky č. } 2 \\
\text { v podobe tonálneho vyrovnania }\end{array}$ \\
\hline A": návrat hlavného motívu v modifikácii \\
\hline $\begin{array}{l}\text { Rozsiahla kóda: úvodný úsek - motivická } \\
\text { práca s materiálom z dielu B } \\
\text { záverečný úsek - tempový kontrast, } \\
\text { uzavretý hlavným motívom z dielu A }\end{array}$ \\
\hline
\end{tabular}

\section{Hudobná analýza jednotlivých častí}

Tanec

Prvá čast' suity je koncipovaná v sonátovej forme na malej ploche. Začína sa expozíciou, uvedením hlavnej myšlienky Andante con moto v rámci tematickej plochy centralizovanej in A. Už tempový predpis myšlienky predostiera noblesnost' tanečného gesta, ktoré sa prednáša v pomalšom tempe. Prekvapivá je rytmická štruktúra a meniace sa metrické členenie v celej časti, ked’sa prechádza z pravidelného na nepravidelný rytmus, pričom pulz je pravidelný a prebieha v štvrtových hodnotách. Hlavná téma pozostáva z viacerých motívov. Prvé dva takty sa vyznačujú pravidelným statickým rytmom v ostinátnom staccate - ide o „anticipáciu sprievodu“, pričom však aj táto figúra počas hudobného priebehu nadobudne tematický rozmer. Charakteristickým znakom je intervalová stavba v base (kvinty) a strednom hlase (kvarty), pričom pri ich melodickom postupe sledujeme sekundový posun. Nosným elementom je bas, ktorý nastupuje na prízvučnú prvú dobu. Dvojtaktový motív v polohe spodného registra evokuje svojou zvukovostou tajomnost'. V 3. takte sa začína rozvíjat' melódia s príznačným triolovým rytmickým motívom, ktorý sa v d’alších taktoch modifikuje do rôznych podôb. Úvodná zádumčivost' sa odrazu zmení na žartovnost'. 
Príklad 1: Úvod skladby (t. 1 - 5)
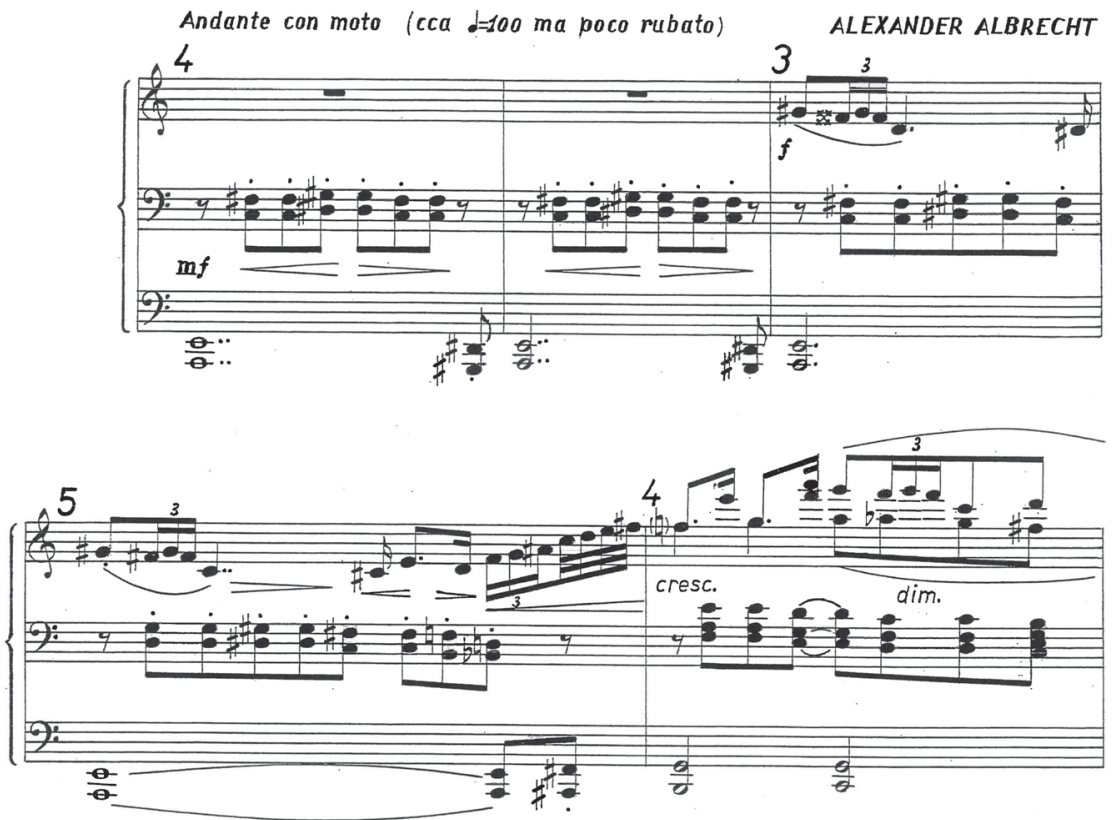

Tento dvojtaktový motív (t. 3 a 4) teda uvádza hlavnú tému so zretelne jasnou melodickou líniou, pričom intervalová stavba sprievodu v tret’om takte ostáva nezmenená. Okrem sprievodu stredného hlasu - tóny c, fis - sa aj v melódii hned' na začiatku objavuje interval zväčšenej kvarty (tritón) - tóny gis, $d$ - ktorý rámcuje rytmický motív a dodáva mu okrem žartovnosti aj určitú dávku grotesknosti. Štvrtý takt prináša okrem zmenenej intervalovej štruktúry motívu aj celotónový beh, ktorý ústi do d’alšej dvojtaktovej motivickej variácie. Je síce odvodená z pôvodného motívu, dochádza však k zmene registra a závažnejším zmenám štruktúry. Rytmické a harmonické zahust’ovanie prináša zmenu v sprievode a melódii. Pôvodnú intervalovú štruktúru v sprievodnom strednom hlase strieda akordická bez razantného staccata, melódiu tvorí dvojhlas. Motív je harmonicky bohatší a rytmicky pestrejší.

Príklad 2: Melodické a rytmické obohatenie motívu

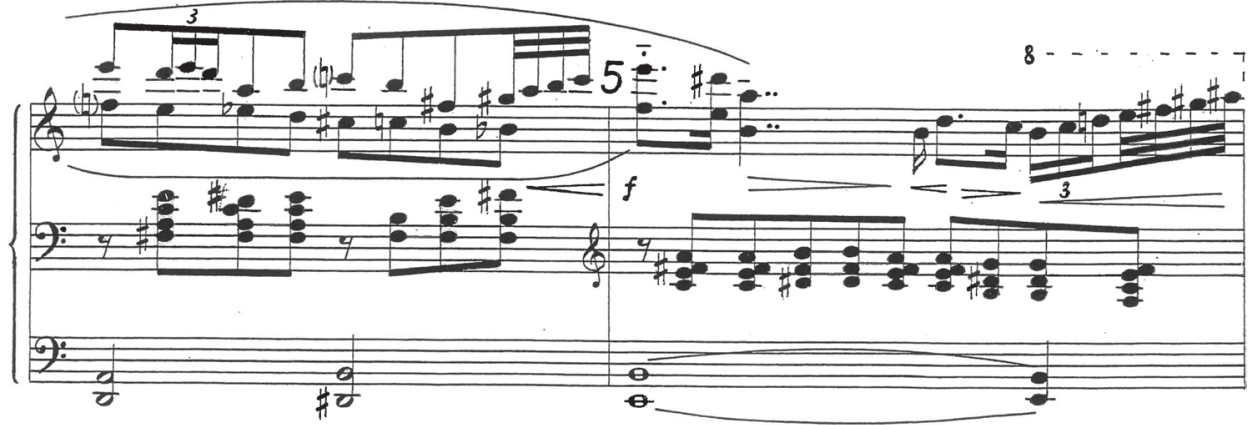


Sprievod pri d’alšom dvojtaktovom motíve (t. 7 a 8) začína tvorit’ akúsi oporu melodickej línii, ktorá pozostáva z rýchlych behov a vel'kých intervalových skokov. Dochádza tak k väčšiemu napätiu a vyburcovaniu témy, ktorá zakotví in D vo fortissime. Skladatel' využíva postupnost' sledu tónov $v$ base príbuzných tónin kvartového kruhu - tóny $d, g$, $c, f$, hes. Zmena nastáva pri zvukovom vrchole témy vo fff (t. 11), kde už výrazne využíva chromatiku a modifikáciu rytmického motívu z triolového rytmu na bodkovaný. Celý tento úsek je charakteristický väčšou pohyblivostou basu a stredného hlasu podporujúcich melodickú líniu.

Príklad 3: Dynamický vrchol témy v rytmickej modifikácii (2. takt ukážky)

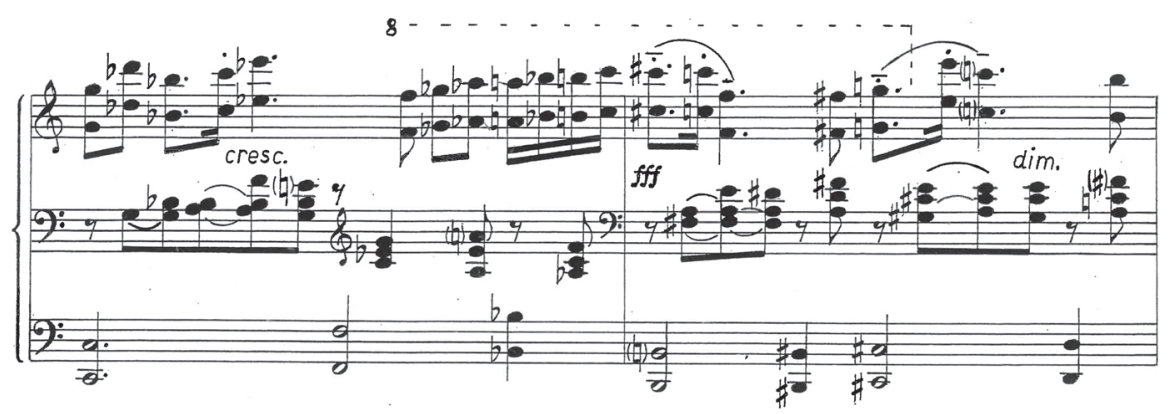

Následne sa tok harmonického priebehu upokojí a dostáva sa spät’ k úvodnému motívu, ktorý na rozdiel od svojho prvého uvedenia zaznieva $v \mathrm{mp}$ a centralizácii in E (dominanta k A). Tento pättaktový úsek (t. 13 - 17) predstavuje akúsi metamorfózu prvého uvedenia témy, v ktorej sa objavuje aj nový element - trilkovanie melódie, ktoré vyústi do záveru hlavnej tematickej plochy ako i samotného vrcholu prvej časti.

Záver hlavnej tematickej plochy sa vracia k centralizácii in A. Celý šesttaktový úsek pôsobí romantizujúco s jasným tonálnym ukotvením, dodávajúc tak hlavnej téme zvukový kontrast - rámcuje celú tematickú plochu. Harmonickú farebnost' i zvukovú pestrost' dotvárajú septakordy v priebehu prvých dvoch taktov, pričom druhý takt pôsobí ako echo (t. 18 - 19). Zaujímavý je harmonický postup s využitím akordov chromatickej terciovej príbuznosti (a-c-e), (c-e-g-hes), (e-gis-h). Oživenie harmónie sa $v$ tomto slede akordov ukazuje aj v aplikácii dominantného septakordu - tóny c-e-g-hes, ktorý sa rozvinie do jasnej tóniny E dur v trvaní dvoch taktov.

Medzivetný úsek prináša výrazový a tempový kontrast. Začína sa kontrastnou myšlienkou Poco più lento v zasnenej, híbavej a zvukovej tajomnosti. Príznačná je bodkovaným rytmom a odtahmi s repetitívnostou prízvučnej a neprízvučnej doby v melódii, ktorá tak vytvára určitú naliehavost’ a zároveň napätie vo výraze. Naopak, bas si udržiava statickejšiu polohu s chromatickým postupom smerom nahor. Táto chromatická postupnost' zaznieva aj vo vrchnom hlase melódie v protipohybe. Akoby bol druhý zvukový kontrast myšlienky založený na statickej pulzácii vrchného a spodného hlasu $v$ unisone. 
Príklad 4: Medzivetný úsek v chromatických sledoch basu a melódie

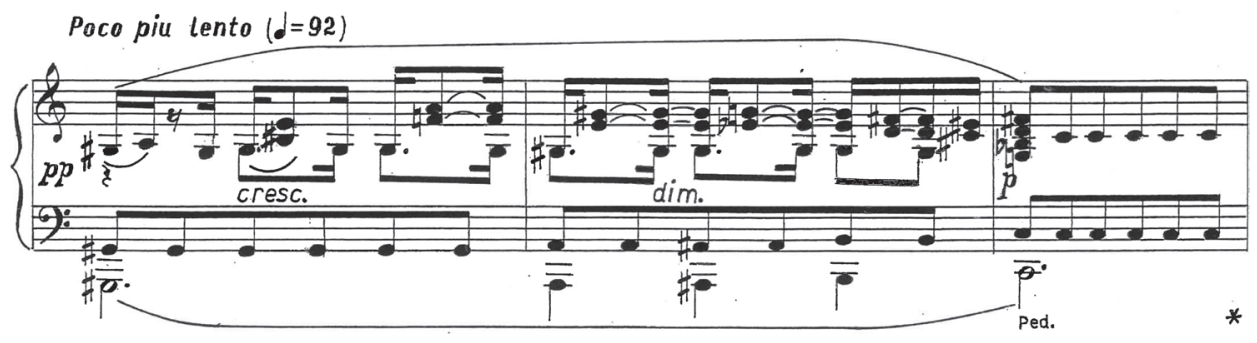

Vedlajšia téma je oproti hlavnej harmonicky menej stabilná. Jej centralizácia je in B. Kontrastná téma prináša výraznú zmenu v agogike - skladatel’ v zápise používa interpretačné poznámky ako quasi improvisato, molto espressivo, a tempo tranquillo, teneramente, ktoré sa vymykajú tanečnosti a málo s ňou korešpondujú. Zmena nastáva aj v pravidelnej rytmickej pulzácii šestnástinových nôt v sprievode, ktoré napomáhajú udržiavat' dynamickost' pohybu. Úsek vedlajšej témy evokuje zasnenost', nežnost’ a zároveň nostalgiu približujúc sa tak romantickému nádychu lyrickosti či intermezza s pokojným a upokojujúcim pôdorysom. Motív je špecifický výskytom priet’ažných tónov pripomínajúc tak skladobný štýl J. Brahmsa (pozri Intermezzo op. 117 č. 2), ktorému je motív vel'mi podobný. Téma sa začína na dominante (F dur) hlavnej tóniny in B.

Príklad 5: Vedlajšia téma v pravidelnej pulzácii šestnástinových nôt

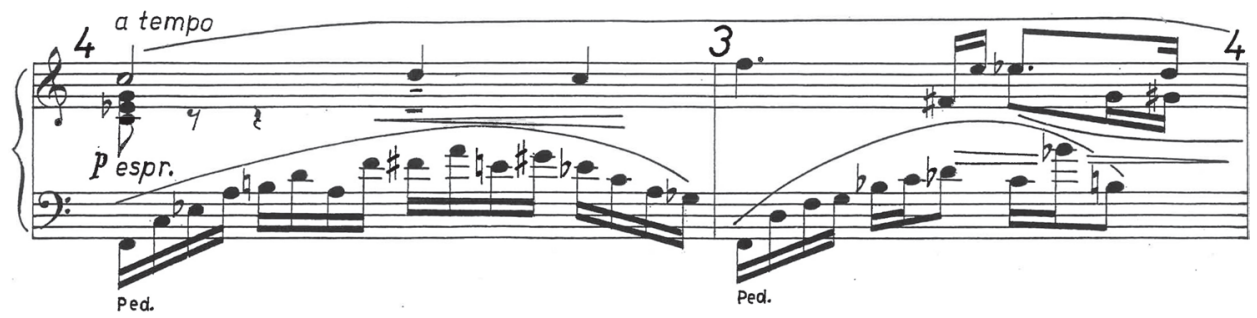

Základným stavebným prvkom tohto úseku je dvojtaktový motív, ktorý skladatel' obohacuje dvojhlasom, rytmickou variáciou ako i jeho rozšírením. Používa sledy akordov chromatickej terciovej a sekundovej príbuznosti. Pre harmonický priebeh a jeho napredovanie sú to charakteristické akordy - h mol, D dur, F dur (t. 37 - 38). V d'alšom priebehu môžeme vidiet' sekundovú príbuznost' - akordy des mol a es mol (t. 44 - 45). V závere tejto tematickej plochy skladatel' využíva ako „hybný motor“ motív z pôvodného dvojtaktia pozostávajúci z väčších intervalových skokov charakterizujúci tematickú koncíznost'. Vedlajšiu myšlienku skladatel' ukončuje prekvapivým alterovaným septakordom. 
Príklad 6: Alterovaný septakord so septimovou štruktúrou - tóny dis-cis-a-gis (3. takt ukážky)

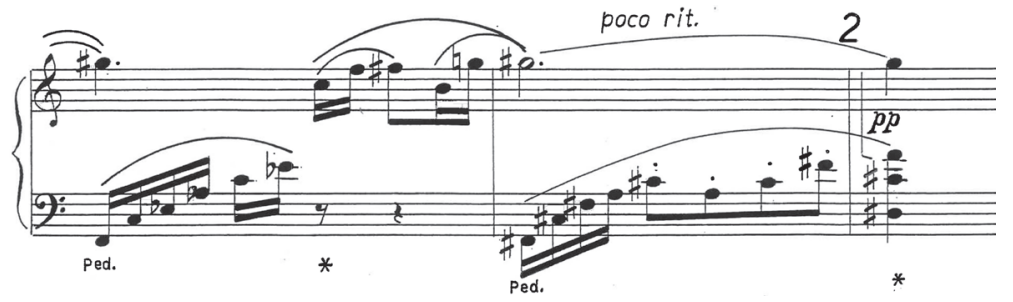

Rozsiahle rozvedenie motivicko-tematicky spracúva materiál z expozície, pričom jeho samotný úvod sa začína uvedením novej myšlienky. Rezký, svižný začiatok evokujúci pochod prináša tiež rytmický kontrast. Začína sa in F ako dominanta k centrálnemu B v jeho d’alšom priebehu. Po úvodných štyroch taktoch zaznieva tonálne jasná harmónia. Rázny a zretel’ný tematický materiál v B dur (t. 59 - 60) svojím charakterom a zvukovostou evokuje klasické vzory. Melódia pripomína stupnicový beh s jednoduchým sprievodom harmonickej línie striedajúcich sa akordov B dur - F dur. Charakter myšlienky sa tak mení na oslavný, vítazný, korešpondujúc s d’alším priebehom. Od t. 61 sa zvuk nesie v znamení fanfár, tvorených striedajúcimi sa akordickými spojmi (B - As, $\left.\mathrm{Es}^{7}-\mathrm{As}, \mathrm{Es}^{7}-\mathrm{B}\right)$. Tonálne centrum sa tak na malú chvílu zmení (As dur), ale ukončenie novej myšlienky neočakávaným zvonivým basom v nízkej polohe kontraoktávy v mf je znova v tónine $B$ dur. Návrat hlavného motívu z expozície prichádza v permutácii v trvaní dvoch taktov s akordickým staccatovým sprievodom vrchného hlasu v sekundových postupoch smerom nahor.

Príklad 7: Hlavný motív zaznieva v permutácii (3. - 4. takt ukážky)

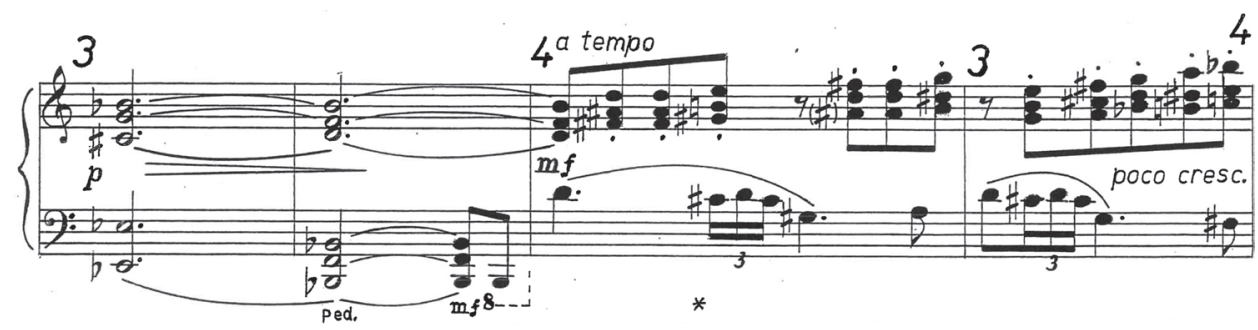

Kontrastná myšlienka sa v rozvedení neobjavuje. Skladatel' sa zameriava iba na hlavnú tému a jej motivické spracovanie, ktoré rôzne variuje, rozširuje, opakuje a rytmicky obmieňa. Skladatel' kombinuje tiež dvojtaktové motívy z expozície a používa ich v inom slede. Dôležitou súčastou podobne ako v kontrastnej myšlienke sú interpretačné poznámky skladatel'a, ktoré prispievajú k väčším kontrastom uvedených motívov. Objavujú sa názvy ako animato, poco agitato, più agitato, tranquillo, dokonca aj appassionato. Špecifickým znakom je nadpočetné uvedenie triolového motívu. Po permutácii sa motív objavuje in C obohatený a rozšírený o šestnástinové noty, ktoré pokračujú v nadväznosti a kombinácii motívu bodkoveného rytmu (t. 70 - 72). Ďalšie uvedenie triolového motívu je in Es (t. 74 - 75). 
Vrchol rozvedenia je podobný ako v expozícii, nadobúda však väčšiu pohyblivost' vd’aka šestnástinovým notám - oproti prvému uvedeniu sú záverečné v inverzii. Aj predposledný nástup triolového motívu je v inverzii postupujúc smerom nadol, pričom nasleduje rozšírený motív bodkovaného rytmu v protipohybe so spodným hlasom v zdvojení sopránu.

Posledné uvedenie motívu (t. 86 - 87) v chromatickej postupnosti basu vyústi do záverečnej časti rozvedenia. Rozklady v sprievode zahalené v tajomnosti meniacej sa harmónie každého taktu sprevádza kolísavá melódia bodkovaného rytmu v slede tercií, neskôr zväčšených akordov. Gradovanie rozvedenia nastáva v zmene metrickej štruktúry (trioly - duoly), pričom akordy v melódii postupujú v chromatickom slede.

Vrchol prichádza vo vášnivom zvonivom zvuku zdvojeného sopránu v unisone so zahusteným triolovým akordickým sprievodom v jeho statickej pulzácii, ktorý postupným spomalením a stišovaním vyústi do prekvapujúceho dominantného septakordu.

Príklad 8: Dynamický vrchol zakončený dominantným septakordom - tóny c-e-g-hes

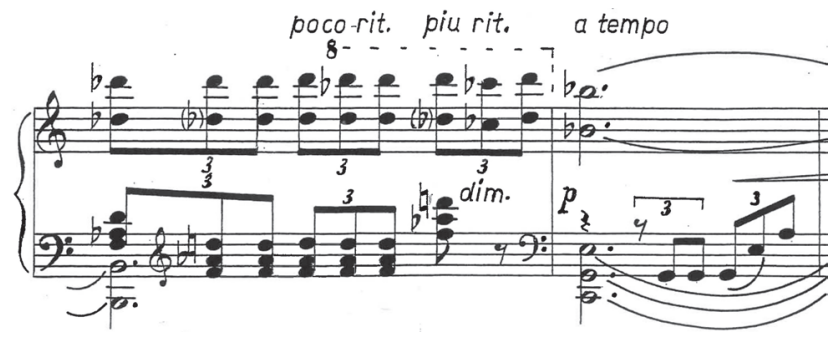

Repríza má inverznú podobu. Tým, že materiál hlavnej témy dominoval v rozvedení, repríza sa zameriava na oblast' vedlajšej témy, ktorou sa aj začína. Na rozdiel od expozície je centralizovaná in Des, pričom tento vztah nahrádza tonálne vyrovnanie. Začiatok témy sa nesie v rovnakej lyrickosti a atmosfére pokoja. Jej priebeh sa začína postupným zahustovaním šestnástinovými notami a zmenou rytmu na $6 / 8$, čo kulmináciou prerastie do pättaktového motívu evokujúceho fanfáry z rozvedenia (t. 122 - 126). Repetitívnost' basu plynule prechádza do medzivetného úseku, ktorý oproti prvému uvedeniu udržiava väčšie napätie chromatikou v base s melódiou v protipohybe. Celý proces zvukovo vrcholí vítazným motívom v akordických štruktúrach centralizovaných in A (Pesante, t. 135 - následne pribúdajú kvartové štruktúry).

Záver celej časti uzatvára kóda (repríza hlavnej témy) evokujúca návrat úvodného motívu z expozície. Postupné skracovanie motívu, spomalovanie hudobného procesu ako i jeho stišovanie sa stáva reminiscenciou končiacou záverečným akordom in A (bez tercie).

\section{Humoreska}

Druhá čast' prináša priam rokokový nádych s l'ahkou hravou atmosférou. Predkladá a tlmočí skladatelov zmysel pre humor a vtip, ktorý sa nesie celou skladbou. Hudobný proces celej časti vyrastá z jednej myšlienky, ktorá je zložená z viacerých tematických jadier a dôsledne premyslenej tematickej práce. 
Rozsiahly diel A predkladá hlavný tematický materiál pozostávajúci z viacerých menších motívov - motivického materiálu. Začína sa dominantným staccatovým motívom v pravej ruke, ktorý zároveň s jedným tónom z predtaktia vytvára sekvenčný postup ústiaci do centrálneho tónu $d$. Práve tento úvodný jednotaktový motív je klúčovým prvkom, ktorý je podrobený d’alšiemu motivickému spracovaniu. Objavuje sa aj v nasledujúcom dvojtaktovom motíve centralizovanom na tóne $d$ v zrýchlenom šestnástinovom zaznení (v druhom prípade kvintola, t. 2 - 3), pričom sprievod je sekvenčne posunutý o sekundu nadol.

Príklad 9: Úvod skladby v markantnej rytmickej a melodickej živelnosti

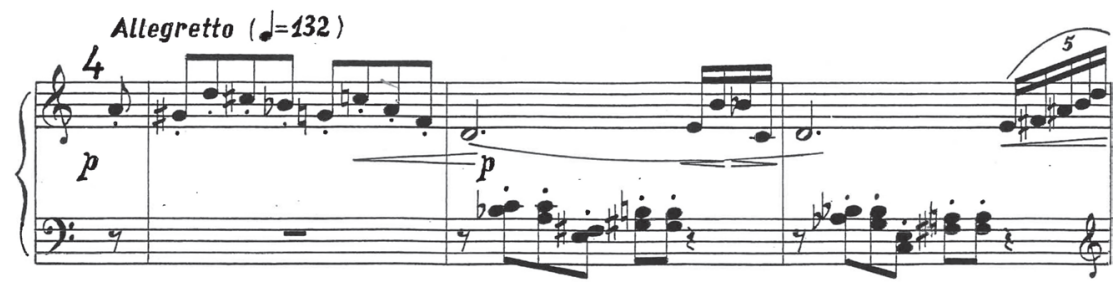

Skladatel' s motívom pracuje aj d’alej, ked'zaznieva vo vol'nej inverzii (t. 4) s chromatickým postupom tercií v sprievode. Následne pokračuje tematickým materiálom z úvodu rytmicky a artikulačne upraveným, d’alej jeho variáciou s jasným rozčlenením hlasov, čím sa na malý okamih vymaňuje zo zvukovej striedmosti k bohatšej harmónii s jasnou oporou v base. Po opätovnom odznení úvodného motívu nasleduje nový motivický materiál, ktorý skladatel' obohacuje trilkami a triolami (t. 10 - 11). Chromatické postupy v melódii a akordickom sprievode v protipohybe, ako i často sa meniaca dynamická škála na malom dvojtaktovom úseku, vytvárajú napätie a nepokoj. Zúženie motívu (t. 12 - 13 ) sa objavuje v zmenenej zvukovosti vd’aka predpísanej pedalizácii a rozloženým akordom v sprievode. Záverečné uvedenie staccatového motívu, tentokrát centralizovanom na tóne $c$, vyústi do akordických súzvukov končiac jasným akordom $C$ dur v krajných registroch nástroja.

Zmena prichádza nástupom dielu B, ktorý má expanzívny charakter. Statickost’ pravidelne pulzujúceho sprievodu, v ktorom sa postupne zvuková stránka zahust'uje pridávaním tónov, vytvára spolu s tahavou melódiou tajomnú atmosféru akoby zahalenú v hmlistom citovom rozpoložení. Ťahavost’ dotvárajú prietahy v melódii ako i samotná pedalizácia. Skladatel' pracuje s motívom z úvodu, pričom v rozdielnej artikulácii nadobúda iný rozmer pripomínajúci žalostné vzlyky.

Príklad 10: Kontrastný diel B príznačný melodickými priet’ahmi

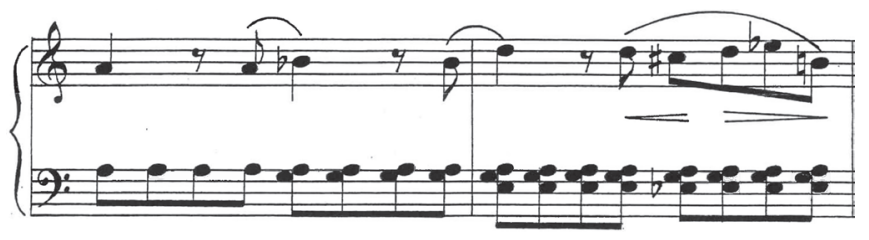


Hutnost’ akordickej sadzby, ktorá pokračuje v motivickom spracovaní, doplńna sled rozložených akordov v sprievode. Harmónia tvorí pestrofarebnú splet’ v široko sa rozpínajúcej sadzbe. Melódia nevybočuje do vel'kých intervalových vzdialeností, naopak, postupuje sekundovými krokmi s dvojtaktovou zmenou metrickej štruktúry. Následne sa čiastkový motív objavuje vo svojej pôvodnej staccatovej podobe s plynulým postupom k prechodnému úseku (vychádza z dielu A), v ktorom skladatel' spracúva záverečnú kvintolu v rámci novo koncipovanej hudby (t. 28). Zvučné septakordy striedajúce sa s rýchlym kvintolovým behom sú ozvláštnené dynamickými odtieňmi. Proces vrcholí v zvonivom registri pravej ruky v podobe klesajúcich akordických sledov zložených $z$ priet’ahov, postupne stišovaných do $p p$.

Centrálny úsek, ktorý zastupuje rozvedenie v rámci exponovania všetkých tematických plôch, predstavuje určitú dohru. Je špecifický striedaním dvoch odlišných charakterov - molto espressivo (falošným pátosom) a scherzando. Prvý plynie v rozvláčnej a pokojnej zvukovosti, zatial' čo druhý je razantný a stručný. Po ich prvom uvedení ich skladatel' uvádza iba čiastkovo v skrátenom tvare s viacnásobným opakovaním.

Príklad 11: Dva kontrastné motívy (2. - 3. takt ukážky)

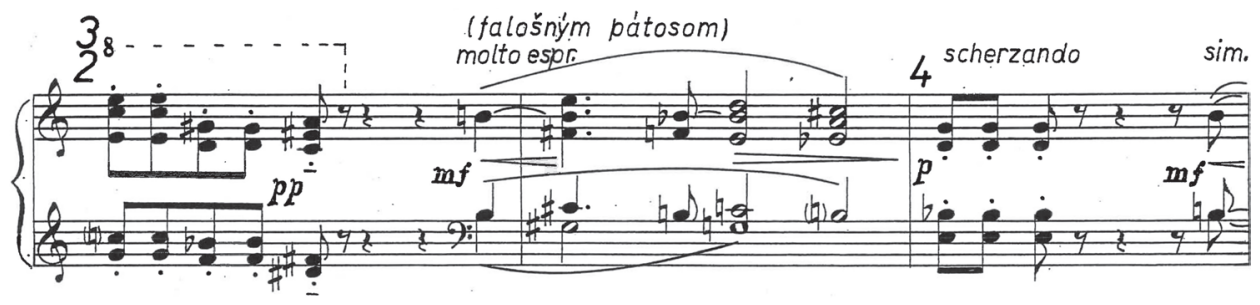

V repríze skladatel' s motivicko-tematickým materiálom narába vol'ne - v zásade inverzne, pričom jednotlivé úseky uvádza v rozličných kombináciách a v odlišnom poradí. Diel A' uvádza glissandom rozvinutým do motívu obohateného trilkami a triolami, ktorý skladatel' rozširuje o dva takty. Prvé uvedenie staccatoveho motívu sa objavuje v permutácii a zároveň inverzne (t. 47 - 48), pričom skladatel' používa žartovnú formu spojenia tohto motívu s nezmenenou verziou pôvodného motívu z úvodu. Zvukové napätie necháva gradovat' repetíciou štyroch tónov odvodených z celotónového motívu, ktoré plynulo prechádzajú k uvedeniu tematického materiálu z úvodu. Obmena prichádza $v$ inverznej melódii a so zmenenými intervalovými postupmi v lavej ruke (t. 55 - 56). Následne skladatel' zaujímavým spôsobom variuje motív, ktorý postupne skracuje, pričom z neho ostáva už iba čiastkový motív v protipohybe vrchných a spodných hlasov. Materiál z dielu B (t. 63 - 68) vkladá s ciel’om vyvolania kontrastu žartovnosti a chvíl'kovej zasnenosti, čím vyniká záver v podobe posledného uvedenia hlavného motívu posilneného unisonom.

Humoresku ukončuje rozsiahla kóda, ktorá nahrádza skrátený diel B. Podobne ako v prvej časti, aj v závere humoresky skladatel' necháva postupne zanikat' jej faktúru a hlasitost'. Harmonický priebeh centralizuje in D. Kóda je charakteristická tým, že v nej skladatel' uvádza krátke útržky motívov vyskytujúcich sa vo všetkých troch dieloch. Už samotné označenie Poco più lento predostiera jej pomalší úvod. Šestnástinové noty 
v melódii skladatel' mení na osminové, pričom tak motív vyniká pokojnejšou pulzáciou a zretel'nejšou artikuláciou.

Príklad 12: Začiatok kódy v pokojnejšej rytmickej štruktúre osminových nôt

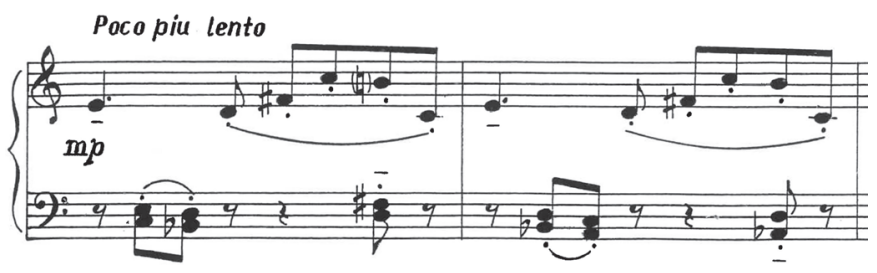

Zmena metra predkladá čiastkový motív z kontrastného úseku, po ktorom nasledujú čisté konsonantné akordy vítazného charakteru. Následné vloženie rýchlych kvintolových behov predstavuje gradačný moment k vyvrcholeniu klesajúcich akordických sledov končiacich vo forte. Záver kódy spracúva už iba staccatový motív, s absenciou sprievodu na jej začiatku. Dlhé znenie tónu $d$ v base, nad ktorým doznievajú posledné tóny úvodného motívu, sa objavuje v permutácii od t. 91 ukončujúc tak celú skladbu. Postupné spomal'ovanie a stišovanie hudobného procesu vrcholí v podobe unisona v úplnom ppp.

\section{Uspávanka}

Uspávanka, ktorú skladatel' koncipuje ako tretiu v rámci cyklu, sa vymyká atmosfére predchádzajúcich dvoch častí a svojím charakterom vyvažuje ich živelnost’ a energickost'. Už zo samotného názvu je zrejmé, že sa nesie v pokojnej, lyrickej a zasnenej nálade. Vyznačuje sa plynulost’ou, jednoduchou melodickou líniou bez akýchkolvek kontrastných výkyvov, ktoré by mohli narušit’ jej kontinuitu a l’ahkost'. Odkláňa sa tiež od sladkého sentimentálneho nádychu, ktorý by nemusel korešpondovat’ s celým cyklom. Zaujímavostou je, že Albrecht Uspávanku skomponoval k narodeniu dcéry svojho kolegu Štefana Németha Šamorínskeho, ktorý bol jeho dlhoročným priatelom a kolegom na Mestskej hudobnej škole. ${ }^{5}$

Tretia čast' cyklu s tempovým označením Andante poco sostenuto sa začína introdukciou, v ktorej sa v sprievode striedajú zväčšené kvintakordy, čím navodzuje atmosféru kolísania či uspávania. Po úvodných dvoch taktoch sa pripája a zároveň začína rozvíjat’ jednoduchá elegická melódia, v ktorej sa objavuje zväčšená kvarta - tón ais, poukazujúca na charakter témy vymykajúcej sa ludovému charakteru. Hoci je melódia centralizovaná in E, zväčšené kvintakordy v sprievode poukazujú na rozšírenú tonalitu.

Príklad 13: Pokojný, akordicky premenlivý sprievod s nastupujúcou melódiou

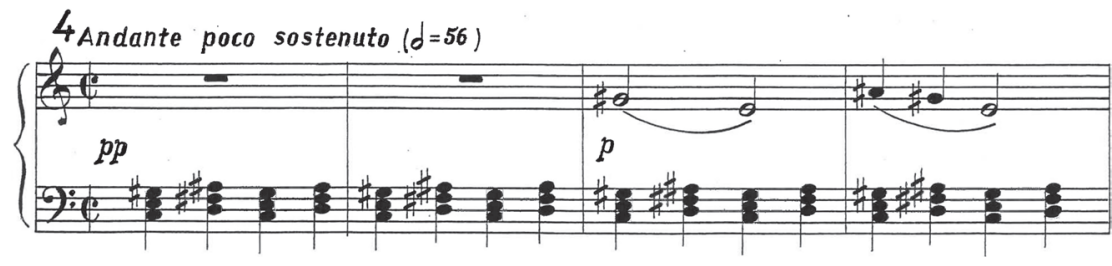


Zmena akordickej štruktúry nastáva na konci prvej štvortaktovej frázy, ked'sa v sprievode objavujú durové kvintakordy v stúpajúcom sekundovom slede. Skladatel' pokračuje rozvíjaním melódie, ktorú uvádza v miernom posune o sekundu vyššie s dávkou väčšej pohyblivosti. Tú dotvárajú osminové noty a sprievodné akordy vymaňujúce sa zo striktnej intervalovej štruktúry, ktorú skladatel' nastolil v úvode. Bohatstvo harmónie dotvára aj rozvíjajúca sa široká sadzba pridaním basovej línie v spodnom registri a rozvláčnost’ akordov v strednom hlase, ktorá je tvorená ligatúrou. Metrická štruktúra sa na chvílu zmení, pričom sa akási kolísavost’ na malý okamih vytratí - dôraz prechádza na prízvučnost' v base (t. 11 - 14). Tento štvortaktový modulačný úsek (zároveň motivická variácia) sa končí na „molovej dominante“ nastupujúceho hlavného tematického materiálu centralizovaného in As, ktorý sa vykryštalizoval postupným uvádzaním motívu.

Príklad 14: „Molová dominanta“ - tóny es-ges-hes-des -, po ktorej nastupuje hlavná téma in As (2. - 4. takt ukážky)

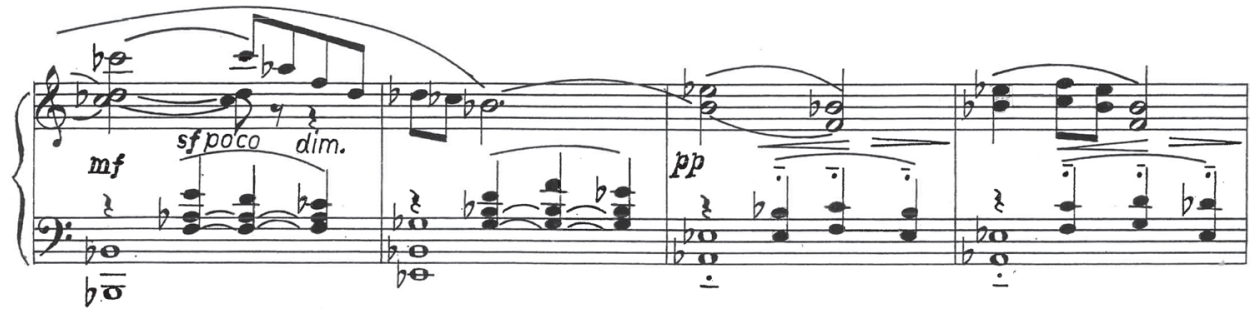

Nastupujúci diel A nastol'uje tému už uvedenú na začiatku skladby. Tentokrát ju však skladatel' ponúka v melodickej variácii obohatenej dvojhlasom. Elegický charakter témy sa odrazu mení na radostnejší a žiarivejší. V trvaní troch taktov pozostáva z intervalovej štruktúry v rozsahu čistej kvarty. Rovnakú farebnost’ vytvára aj sprievod v podobe intervalov, avšak v rozsahu čistej kvinty (prvé dva takty). Melódia a sprievod tak tvoria paralelizmy, ktoré skladatel' ponecháva aj v t. 17 v melódii, odkial' postupuje rozvinutou a jasnou harmóniou obohatenou sledom septakordov v postupnosti - gis $\mathrm{s}^{7} \mathrm{H}^{7}, \mathrm{E}^{7}$, dis $\mathrm{d}^{7}$. Rozvíjanie hlavnej témy pokračuje tentokrát nie v kvartových, ale v terciových štruktúrach melódie s chromatickým postupom basovej línie. Skladatel' tak na malej dvojtaktovej ploche vytvára zvukové napätie a nepokoj vymykajúce sa tak predchádzajúcemu zneniu. Upokojenie v centralizácii in E na jej začiatku prináša štvorhlasnú sadzbu. Tento záverečný osemtaktový úsek je charakteristický tým, že v ňom skladatel' spracúva motív z hlavnej témy. Vkladá ho do vnútorného hlasu - altu - s trblietavou spletou osminových nôt v sopráne a sprievodom pestrofarebnej harmónie akordov spolu s basom v spodnom registri.

Príklad 15: Štvorhlasná sadzba s melódiou v strednom hlase

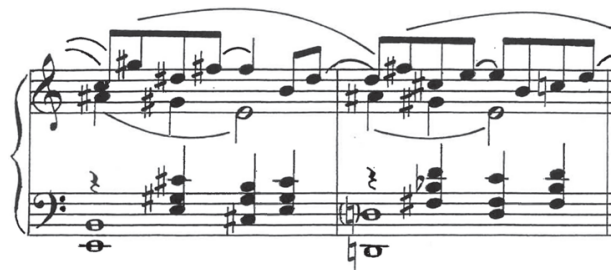


Variačná práca postupne zaniká, pričom skladatel'necháva motív dozniet’ pomocou ligatúry s exponovaním akordov postupujúcich spolu so sopránom k svietivému vrchnému registru, odkial' sa začína diel B. Charakter a zvuková atmosféra tohto dielu plynú v rozjímaní a zasnenosti, pričom na niektorých miestach cítit’ skladatel'ovo orchestrálne cítenie v plnosti a bohatosti širokej sadzby s farebnými kontrastmi a celkovým narábaním so sonorickostou. Neobjavujú sa v ňom descendenčné postupy v melódii, naopak, vedenie melodickej línie koncipuje vol'nejšie. Materiál dielu B je podobne ako pri diele A centralizovaný in As. Začiatok v pp prebieha v zvonivom zvuku melódie a sprievodu vo vrchnom registri v dížke štyroch taktov. Skladatel' tak uvádza prvý dvojtaktový motív, pričom pri jeho druhom uvedení využíva melodickú variáciu. Dôležitú úlohu z hladiska artikulácie a rytmizácie zohráva aj samotný sprievod, ktorého štruktúra sa objaví v priebehu tohto dielu.

Príklad 16: Základný melodicko-rytmický dvojtaktový motív dielu B

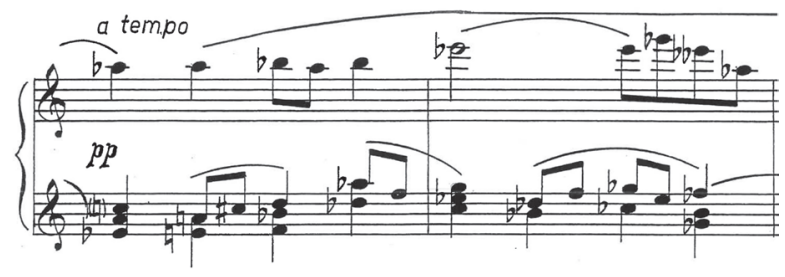

Zvukovou gradáciou rozšírením osminových nôt z motívu dochádza k oživeniu jasnej harmónie. Hudobný proces sa zmenou metrickej štruktúry trocha spomalí v postupnosti akordov chromatickej sekundovej príbuznosti f mol a Ges dur, vrcholiacich do rozloženého septakordu - tóny ces, es, ges, heses (t. 35 - 36). Široká sadzba pokračuje aj v nasledujúcich dvoch taktoch so zdvojeným sopránom v unisone s rytmickou štruktúrou vyskytujúcou sa v sprievode úvodného dvojtaktového motívu. Skladatel' pokračuje rytmizáciou motívu aj v nasledujúcich taktoch použitím inverzného postupu osminových nôt v l'avej ruke (t. 39). Harmonický priebeh sa znova na chvílu upokojí in Es. Postupnou zmenou rytmizácie v rozvláčnejšom znení melódie štvrtových nôt sa hudobný proces ukotví in c (paralelný vzt’ah), pričom sa dostáva k záveru dielu B v opätovnej centralizácii in Es. Sprievodný motív tak zaznieva v žiarivej a jasnej kontúre oboch rúk s nádychom pokoja, akoby sa hudobný proces na malú chvílu zastavil v rozjímaní dokonalého súznenia.

Príklad 17: Upokojenie hudobného procesu v tonálne jasnej harmónii (2. - 4. takt ukážky)

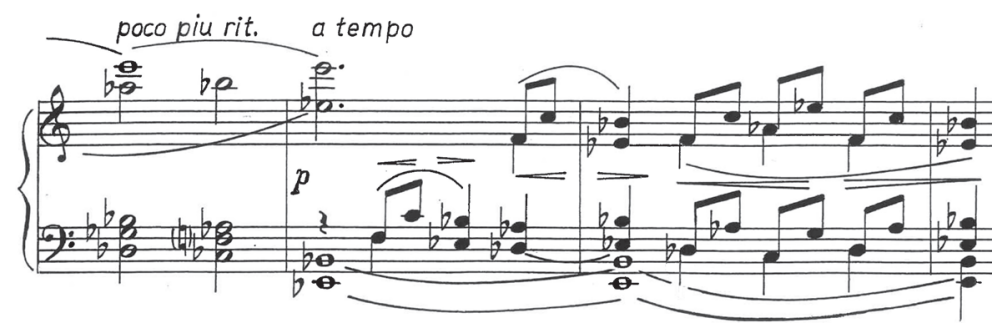


Jeho rytmickou (intervalová štruktúra) a melodickou variáciou s chromatickou postupnost’ou spodného hlasu v base sa skladatel' dostáva k inverznej repríze obsahujúcej prvky rozvedenia uvedením najskôr dielu B v pozmenenej podobe. $V$ úvodných taktoch skladatel' pracuje s hlavným dvojtaktovým motívom. Spodný tón basovej línie posúva poltónovými krokmi smerom nahor s pokračovaním klesajúcich sekundových krokov po t. 52. Melódia pracuje s rozšírením čiastkového motívu, ktorý postupuje tiež smerom nadol. Celý štvortaktový úsek je opät’ v žiarivom vrchnom registri. V chvílkovom znení in Es od t. 53 sa mení štruktúra sprievodu. Rozklady v lavej ruke s pravidelnou pulzáciou osminových nôt nad rozvíjajúcou sa melódiou dodávajú svojou rozpínavostou dynamickost' a zvukovú pestrost', ktorá pokračuje aj d’alej v nástupe hlavnej témy z dielu A v ukotvení in A. Skladatel' ju uvádza vo väčšej pohyblivosti vd’aka aplikácii triolového rytmu. Je pozoruhodné, s akou pestrost'ou skladatel' predkladá základný štvortaktový motív. Prvé dvojtaktie koncipuje v dynamickosti triolového sprievodu s intervalovou štruktúrou melódie, pričom koniec motívu ponecháva statický podla úvodnej introdukcie - akordický sprievod k jednohlasnej melódii. V t. 60 sa objavuje sled klesajúcich akordov, ktoré sú v inverznej podobe oproti svojmu prvému uvedeniu v rámci tematickej plochy.

Príklad 18: Oživenie motívu akordickými rozkladmi lavej ruky s návratom k pôvodnej štruktúre

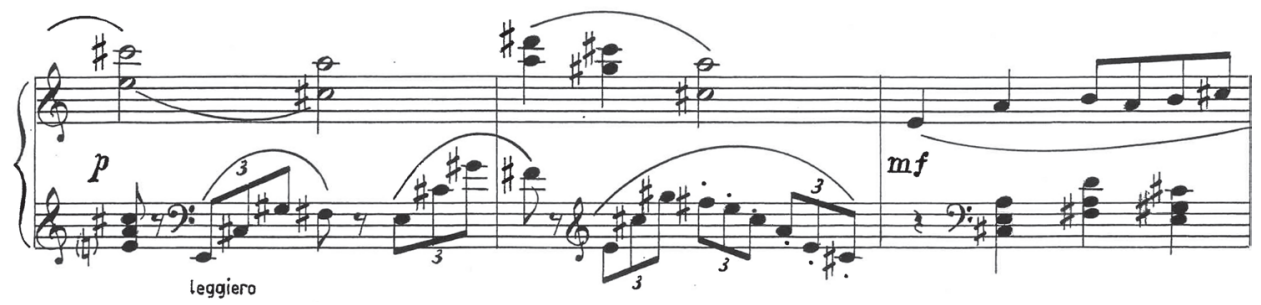

V inverzii skladatel' uvádza aj čiastkový motív z hlavnej témy (t. 63).V nasledujúcich taktoch ho rozširuje a uvádza v rytmickej a melodickej obmene. Tento osemtaktový variačný úsek, ktorý je navyše podporený pedalizáciou, nadobúda rozpínavostou hlasov zvukovú rozvláčnost'. Hudobný proces sa postupne upokojuje a končí sa dominantným septakordom - tóny $h$-dis-fis- $a$-, rozvedeným do tóniny E dur, v ktorej nasleduje repríza.

Opätovné uvedenie hlavného tematického materiálu sa začína v bohatej akordickej štruktúre melódie so zádržou v base - tón e -, ktorá tak dodáva plnost’ a sýtost’ celkovému zvuku. Na rozdiel od úvodu je motivický materiál od t. 79 uvedený v pozmenenej intervalovej štruktúre. Svojou expanzívnost’ou vytvára väčšie zvukové napätie disonantnejšími súzvukmi. Hlavný motív (centralizácia in As) sa posúva chromaticky v oboch hlasoch, pričom tak môže pôsobit' ako žartovný moment, ktorý skladatel' vkladá s úmyslom prekvapenia. Rozšírenie d’alšieho čiastkového motívu uvádza v podobe klesajúcej sekvencie akordov v malosekundovom postupe, pričom nastáva postupné stišovanie a upokojenie hudobného procesu. 
Príklad 19: Postup klesajúcej sekvencie (3. - 4. takt ukážky)

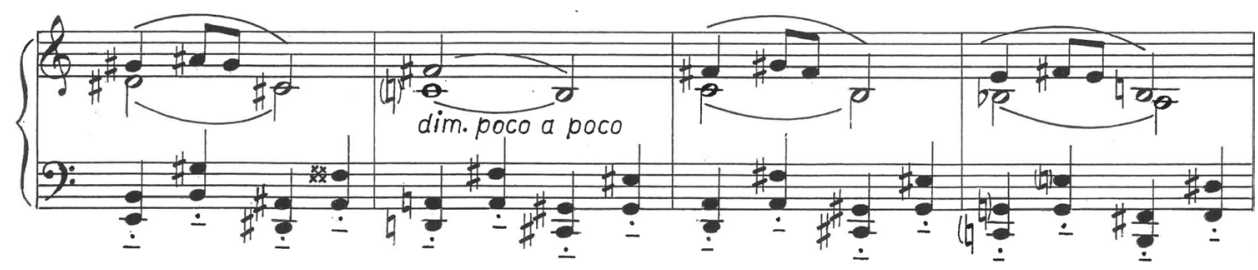

Celú čast' uzatvára kóda, ktorá využíva materiál hlavnej a vedlajšej témy z oboch dielov s variačnou obmenou. Prebieha v híbavej a pokojnej atmosfére začínajúc uvedením motívu z dielu $B$, tentokrát však s väčšou liubozvučnostou a entuziazmom aplikovaním konsonantných akordov. Zaujímavé je spojenie dvoch kontrastných motívov. Prvé dvojtaktie v tónine $C$ dur so zádržou v base tvorí svojou zvukovou rozpínavostou kontrast k nasledujúcemu dvojtaktiu (terciová príbuznost' E dur), ktorého sprievod tvoria durové a zväčšené akordy z úvodu evokujúce kolísavost’ so statickejšou pulzáciou - melódia postupuje inverzne. Skladatel' v tomto protiklade a kontraste pokračuje aj d’alej, ked' motív zaznieva v A dur s pokračovaním rozšíreného čiastkového motívu. Záverečný úsek kódy predstavuje uvedenie hlavného dvojtaktového motívu. Melódia je obohatená farebnejším nádychom septakordu a akordická štruktúra nahradená jednoduchou líniou sprievodu. Jeho postupné skracovanie ako i samotné stišovanie vyústi do záveru, ktorý skladatel' ukončuje zvonivým a radostným akordom v tónine E dur.

\section{Pochod}

Finálna štvrtá čast’ sa vracia k živelnosti a energickému tempovému nasadeniu, ktoré je vykreslené už samotným označením Con moto na začiatku skladby. Je koncipovaná ako sonátové rondo s vel'kou kódou, čo predpovedá širokú škálu kontrastov v hudobnom priebehu troch hlavných tematických plôch. Čast’ sa začína rozsiahlou gradáciou exponovaním markantného, rázneho motívu v štylizácii pochodu, ktorý sa stane základným materiálom tematickej plochy dielu A. Predchádzajú jej štyri takty sprievodu v razantnom staccate a intervalovej štruktúre v rozsahu sekundy, ktorá postupným nabal'ovaním tónov prerastie do akordov. $V$ rámci tejto plochy, ktorá sa nesie v žartovnom duchu, skladatel' kladie dôraz na rytmické bohatstvo a pestrost', ako aj ozdobnost’ dotváranú prírazmi a arpeggiami v sprievode. Zo základného dvojtaktového motívu skladatel' vyčleňuje triolovú figúru a sekundový postup. S týmto základným motivickým materiálom pracuje d’alej v ostatných dieloch. Sprievod prvého štvortaktia postupuje v rovnakej rytmizácii, zatial' čo melódia základného motívu pri d’alšom dvojtaktí podlieha intervalovým posunom so záverečným šestnástinovým behom. 
Príklad 20: Úvod skladby v energickej rytmizácii a melodickej svižnosti
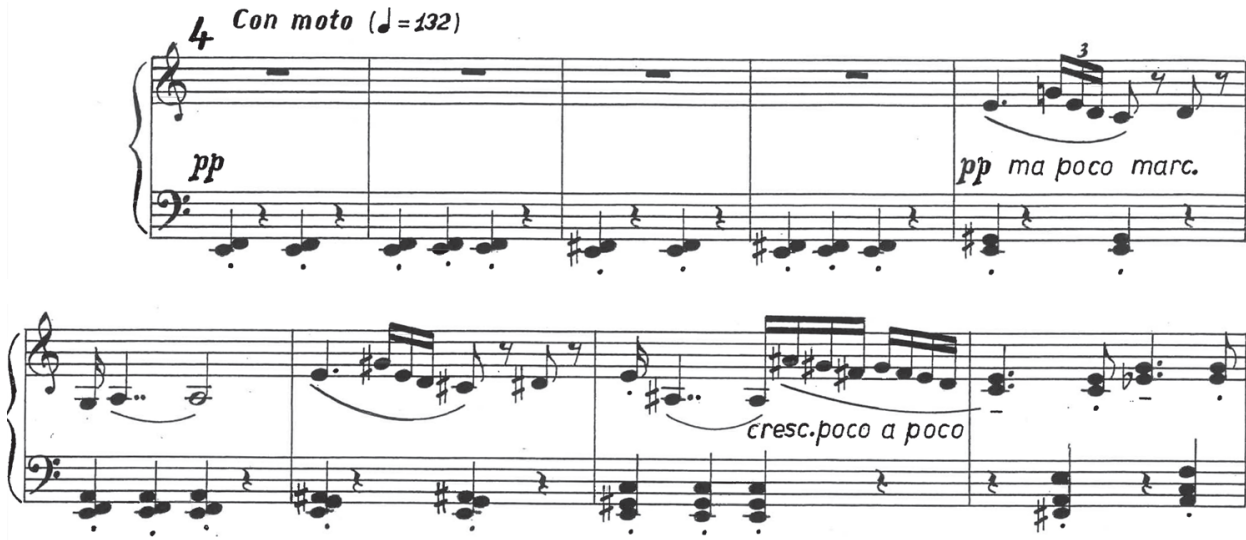

Skladatel'od t. 9 pracuje s rytmickou variáciou sprievodu v synkopických nástupoch a začína rozvíjat’ melódiu v intervalovej štruktúre s dôrazom na bodkovaný rytmus a rýchle šestnástinové behy. Podobne ako v sprievode dochádza k zahustovaniu tónov aj v melódii, čo prerastie do mohutnej akordiky.

Úvodná periodická osemtaktová veta ako základná rozsiahlejšia fráza sa tak stáva základným či už melodickým alebo rytmickým materiálom v pokračovaní hudobného procesu od t. 13. Skladatel's motivickým a tematickým materiálom pracuje pomocou variácií, inverzných postupov, zužovaním, kombinovaním motívov, ako i jeho permutáciou. S bohatou širokou sadzbou prichádza väčšia a robustnejšia zvukovost'. Skladatelovo farebné cítenie harmonických vzt’ahov je tu zretel'né. Melódiu zdvojuje unisono, pričom sprievod už nie je striktne a markantne rytmizovaný, ale nadobúda viac vol'nosti v motivickom priebehu a artikulácii.

Prvé štvortaktie sa začína v radostnej atmosfére s chvíl'kovým ukotvením in C. Je charakteristické sekundovou, miestami až chromatickou postupnostou melódie. Bas si tento chromatický sled udržiava aj v nasledujúcom štvortaktí, v ktorom sa vyskytuje rytmizovaný triolový motív. Zaujímavá je kombinácia základného dvojtaktového motívu v rytmickej modifikácii (trioly nahradené šestnástinovými notami, v nasledujúcom takte sekundový postup), ktorý sa objavuje v sprievode, s čiastkovým motívom v bodkovanom rytme v melódii, taktiež v modifikácii začínajúc in d (t. 21 - 25). Postupné stišovanie hudobného procesu vyvrcholí dominantnými nónakordmi s náhlym a prekvapivým disonantným „výkrikom“ sekundového súzvuku.

Príklad 21: Sled nónakordickej štruktúry ústiacej do disonantného súzvuku v arpeggie

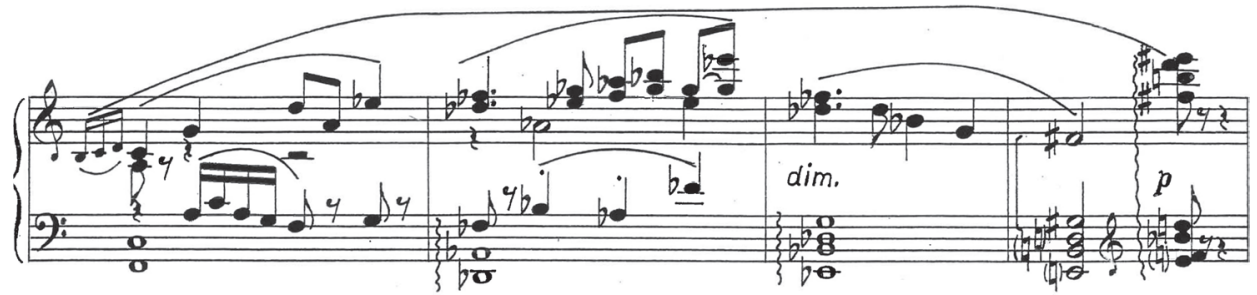


Neočakávaný návrat pochodového sprievodu z úvodu je umocnený akordickou štruktúrou. Hoci jeho návrat autor koncipuje $v p p$, chromatický postup a disonancia predpovedajú náhle vzbíknutie a vyvrcholenie gradácie. Prichádza nástupom hlavného výrazného motívu v rámci tematického komplexu $A$ centralizovaného in $F$.

Hlavný motív zaznieva v triumfálnej zvukovosti evokujúcej zvučné fanfáry. Majestátny zvuk dotvára aj spodný register basových tónov, ktoré pripomínajú hlboko znejúce zvony. Je vystavaný zo základného dvojtaktového motívu úvodnej témy. Použiva základnú rytmizáciu z triolového motívu, avšak samotnú triolu nahrádza šestnástinovými notami (triolovú figúru nevynecháva, ale ju presúva do spodného registra). Postupuje v inverznej podobe úvodného motívu - najskôr sekundový postup. Skladatel' komponuje melódiu aj sprievod unisono pre väčšie posilnenie zvuku. Zvukový kontrast vytvára vysoko znejúci vrchný register exponovaný o oktávu vyššie vytvárajúc akýsi dialóg s hlboko znejúcim basom v spodnom registri.

Príklad 22: Hlavný motív tematického komplexu A

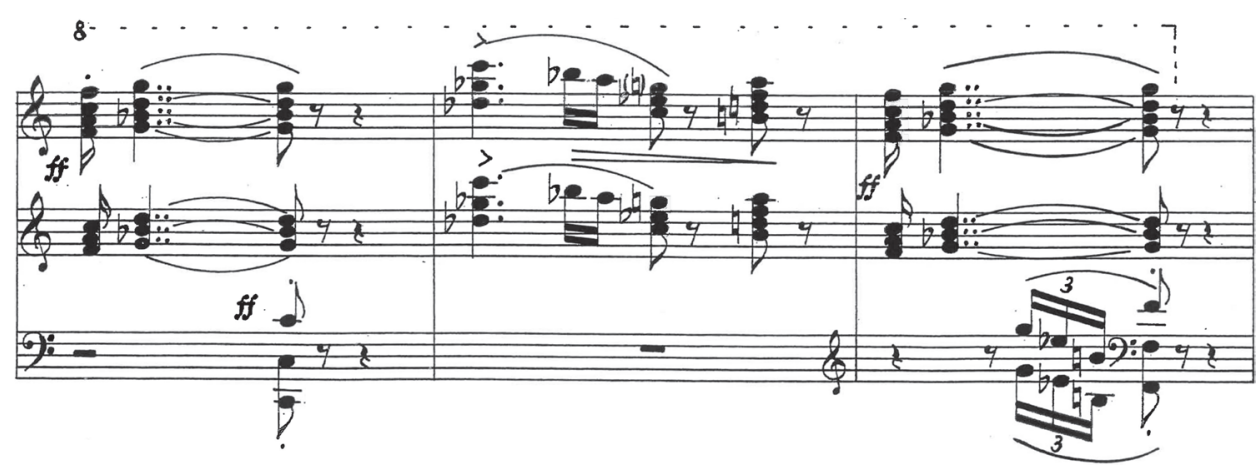

Chvílkové upokojenie zvuku prichádza od t. 36 absenciou basovej línie, pokračovaním čiastkového motívu a jeho modifikácií so stále výrazne znejúcim charakterom (výskyt akcentov). Hlavný, silne znejúci motív sa vracia v zahustenej podobe triolových figúr v inverzii - trioly, sekundový postup. Pribúda aj staticky znejúci motív štvrtových nôt, ktoré skladatel' v závere dielu A mení na osminové noty dosahujúc tak rýchlejší hudobný priebeh. Akordická štruktúra melódie postupne zaniká. Ostáva už iba intervalová, ktorú skladatel' permutáciou spracúva v sprievode s plynulým prechodom $k$ d’alšej tematickej ploche $B$.

Tematickú plochu B skladatel' uvádza na malom úseku; vykazuje rytmickú i charakterovú zmenu. Zmenená rytmizácia na $2 / 4$ takt (dvojdobost') so sebou prináša väčšiu rezkost' a svižnost $v$ tempe odstránením príznačného pochodového rytmu. Téma sa nesie v hravej a šibalskej nálade s prvkami väčšej expresivity. Prvú čast' tvorí intervalová štruktúra sprievodu charakteristická tritónovou stavbou, ktorú posilňuje ostrost' a razantost' staccata. Melódia, ktorú skladatel' koncipuje synkopicky, pozostáva zo sekundových priet’ahov evokujúcich vzlyky umocnené a podporené prírazmi. Spolu so sprievodom tvoria výborný harmonický konsenzus s „potmehúdskym charakterom". 
Príklad 23: Začiatok tematickej plochy B s tritónovou intervalovou štruktúrou

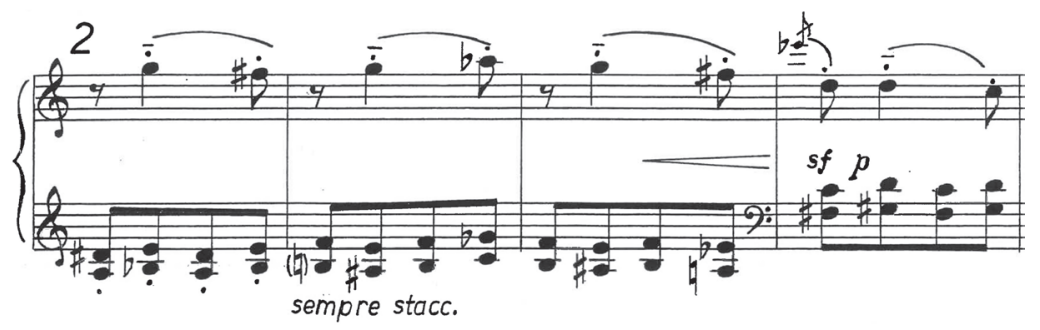

Melódia pokračuje rozšírením čiastkového motívu prírazu s postupne sa meniacou štruktúrou sprievodu na akordickú. Jej druhá poloha od t. 76 má radostnejší nádych s rozvinutejšou a spevnou melódiou vo chvílkovom ukotvení in C. Záver dielu B opät striedajú stúpajúce intervalové sledy vyúst’ujúce do jasného akordu F dur, pričom sa skladatel' vracia spät’ do pôvodného štvordobého rytmu pokračujúc medzivetným úsekom.

Medziveta pozostáva zo základného (markantného) dvojtaktového motívu v pochodovej štylizácii z úvodu. Motív však zaznieva v melodickej transpozícii o interval tercie nižšie (prvky evolúcie). Sekundový postup melódie skladatel' obohacuje stredným hlasom s rovnakou rozšírenou rytmizáciou (bodkovaný rytmus) v inverznej podobe. Na rozdiel od prvého uvedenia zaznieva $v$ zamatovom zvuku spodného registra s trojnásobným opakovaním, pričom sa mení iba akordický sprievod bez akéhokolvek posunu melódie. Práve bodkovaný rytmus sa stáva hlavným dôležitým prvkom, s ktorým skladatel' pracuje v komplexe C.

Rozsiahla plocha C, ktorá je centralizovaná in es, prináša motivickú prácu založenú na rozvíjaní a variácii bodkovaného rytmu z medzivety. Pochodový charakter hlavnej osemtaktovej frázy, ktorú skladatel' uvádza na začiatku, je umocnený pravidelnostou staticky pulzujúceho basu spolu s rovnakou rytmizáciou stredného hlasu v melódii. Príznačná je chromatická postupnost’ oboch hlasov, ktorú svojou o niečo väčšou pohyblivostou oživuje vrchný melodický hlas.

Príklad 24: Tematická plocha C v chromatickej postupnosti oboch registrov

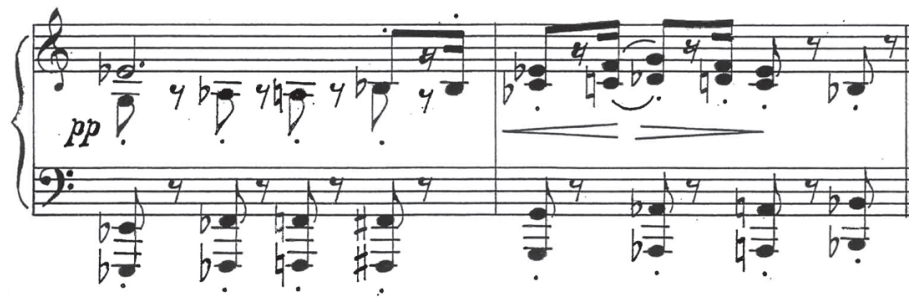

Chvílková zmena nastáva od t. 109 v priebehu šiestich taktov. Sled tercií a basu tvoriacich konsonantný súzvuk opúšt’a chromatické postupy a striktnú pochodovú rytmizáciu. V nasledujúcich štyroch taktoch skladatel' mení faktúru štvorhlasnou sadzbou s pohyblivejším a menej razantným melodickým hlasom (legato namiesto staccata), 
ktorý spolu so sýtym basom a ostatnými hlasmi tvoria bohatšiu a farebnú harmóniu. Návrat pochodu prichádza od t. 115 v paralelnom pohybe basu a stredného hlasu tvoriacich konsonantný súzvuk v intervaloch decimy vo svojej horizontálnej zložke. V závere skladatel' používa už iba čiastkový motív v zmene durového na molový tónorod. V postupnom upokojovaní hudobného procesu sa končí plocha $C$ in es, s priamym nadviazaním na štvortaktový motív úvodného pochodu v úplnom $p p p$.

Po prvom odznení všetkých troch tematických plôch pokračuje skladatel' v ich opätovnom uvedení v modifikovanej podobe. Niektorú tematickú plochu necháva iba v čiastočne zmenenej motivicko-tematickej práci, s inou pracuje v jej väčších obmenách.

Návrat dielu B sa začína prekvapivou dynamickou zmenou vo fortissime basu a melódie unisono - tón c, ktorý je ešte podporený predpísaným pedálom. Rovnako ako pri prvom uvedení skladatel' mení rytmickú štruktúru. Tému transponuje o interval kvinty vyššie (harmonická zmena tohto druhu evokuje tzv. tonálne vyrovnanie), dosahujúc tak väčšiu zvonivost’ a iskrivost' vo vrchnom hlase. Chvíl'kovú centralizáciu in G od t. 141 strieda sekvenčný postup rozvíjajúci čiastkový motív s pokračovaním v melodickej variácii. Následné uvedenie témy z introdukcie prináša viaceré zmeny. Skladatel' začína motívom pochodu, ale v podobe, $v$ akej zaznel v medzivetnom úseku - obohatený o stredný hlas v bodkovanom rytme s chromatickým postupom basu a stredného hlasu. Touto motivickou variáciou sprievodu dosahuje skladatel' určitú naliehavost’ vo zvuku a charaktere. Od t. 158 prichádza téma v mohutnej akordickej štruktúre meniacich sa sledov septakordov rôznej stavby. Na rozdiel od prvého uvedenia rozširuje prvý dvojtaktový motív, pričom v d’alších taktoch nepodlieha vel'kým variačným obmenám. Častý chromatický pohyb oboch hlasov v širokej sadzbe vytvára pestrofarebnú splet’ harmónie, ktorú zakončuje dominantný septakord - tóny es-g-hes-des, k následnej centralizácii in as nadväzujúcej plochy $C$.

Skladatel' prichádza s viacerými modifikáciami. Prvou je rytmická, artikulačná a štrukturálna zmena v sprievode od t. 174. Oktávy nahrádza akordickým postupom štvrtových nôt, ktoré viazanostou svojho legata dopomáhajú k chvílkovej rozpínavosti obohacujúcej markantný rytmus v melódii. Následne dochádza k rozšíreniu čiastkového motívu v terciových, kvartových postupoch a inej intervalovej štruktúre s rytmickým posunom oktáv v base. Proces sa dostáva k poslednému štvortaktovému motívu z introdukcie, kde postupnou kumuláciou harmónie vrcholí diel C. V jeho závere skladatel' využíva chromatický posun akordov v alterácii s aplikovaním dominantného terckvartakordu, ktorý ústi do hlavného motívu v rámci dielu $\mathrm{A}$ centralizovaného in E (dominanta k A dur).

Príklad 25: Alterovaný postup vrcholí dominantným terckvartakordom - tóny fis-a-h-dis

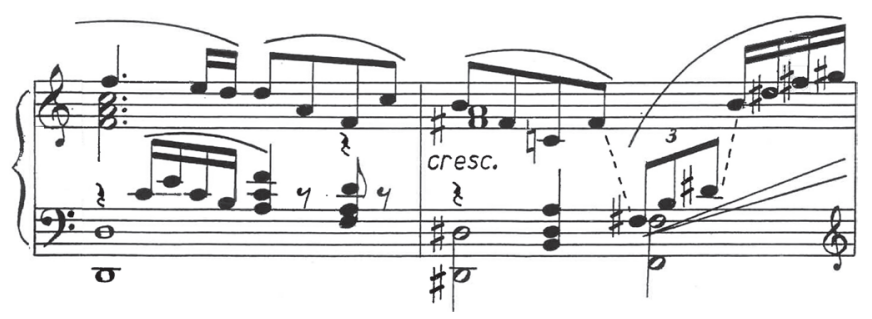


Skladatel' hlavný motív uvádza v skrátenej podobe. Prvé trojtaktie ponecháva v rovnakej motivickej štruktúre ako pri jeho prvom uvedení. Následne rozširuje posledný motív sekundovým postupom a rýchlym behom triolovej figúry, ktorý postupným klesaním prechádza do spodného registra. V descendenčnej postupnosti pokračuje pri d’alšom rozšírení motívu sekundovým postupom a mohutne znejúcim basom.

Rozsiahla kóda prináša zaujímavý priebeh vrcholiaceho hudobného procesu. Začína sa postupnou tempovou a zvukovou gradáciou v intervalovej štruktúre, ktorou vrcholil diel B (pri prvom uvedení). Skladatel' však intervalové postupy rozširuje a rytmicky obmieňa. Melódia je v úzadí. Základným prvkom sa stáva rytmus s dôrazom na efekt klavíra ako bicieho nástroja v jeho plnej expresivite. Postupné zahustovanie triolovou figúrou a šestnástinovými notami vrcholí od t. 233 s tempovým označením Vivo v centralizácii in A. Záver kódy sa vyznačuje rozvíreným a búrlivým zvukom s folklórnym nádychom rezkého tanca. Zakončujú ju práve šestnástinové noty, ktorým skladatel' nedal vel'a priestoru v priebehu celej časti. $V$ rámci prvého dvojtaktia postupujú rýchle sekvenčné sledy šestnástinových nôt s ostrým pochodujúcim rytmom sprievodu v postupnosti akordov sekundovej príbuznosti - A dur, G dur, F dur, G dur. V nasledujúcom dvojtaktí skladatel' túto konsonantnost' porušuje intervalovou zmenou (chromatický posun).

Príklad 26: Záver kódy v pravidelnej pulzácii šestnástinových nôt

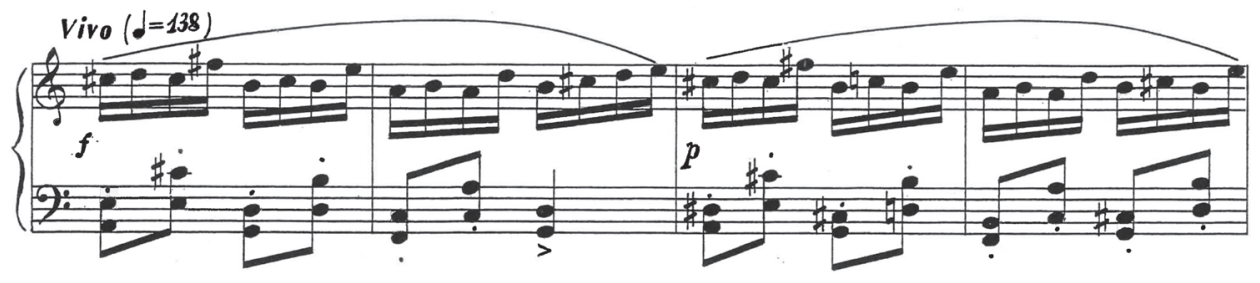

Následne pracuje už iba s terciovou príbuznostou - obmenou tónin A dur, F dur. Opakujúcou sa figúrou šestnástinové noty prerastú v rýchly beh rozloženého akordu d mol so zádržou v base s aplikáciou melodického tónu hes. Hudobný proces sa na malý okamih vráti do pôvodného tempa v zaznení čiastkového motívu z prvého uvedenia dielu A. Posledný rýchly sled figúr sa začína v inverznej podobe melódie so sprievodom oktáv v akordických sledoch - e mol, B dur, d mol, g mol. Skladatel' záverečný rýchly beh zahust'uje akordickým sprievodom uvedením d’alšieho materiálu z introdukcie s rovnakou akordickou štruktúrou - rozklad s arpeggiom. Celý hudobný proces vrcholí hlavným motívom so záverečným jasavým akordom A dur. Albrecht tak rámcuje celú čast' tematicky, zároveň celý cyklus harmonicky.

\section{Záverečné zhrnutie}

Hoci Albrecht dáva štvorčast’ovej kompozícii pomenovanie suita, nie je to také jednoznačné, ked' berieme do úvahy kontrastnost' jednotlivých častí. Z hladiska konceptu ide o sonátový cyklus. Prvá čast' je v sonátovej forme, druhú čast' zastupuje scherzo, 
tretia je pomalou lyrickou čast’ou a štvrtá čast’ má formu sonátového ronda. Tonálna centralizácia jednotlivých častí vykazuje tradičnú koncepciu harmonickej kadencie in A vychádzajúc z jej základných tónov. Prvá čast', ktorá je centralizovaná in A, sa končí akordom bez intervalu tercie. Druhá čast' je centralizovaná in D. Hoci obe témy v úvode tretej pomalej časti sú centralizované in As, končí sa akordom E dur. Štvrtá čast' sa rozsiahlou kódou opät’ vracia k centralizácii in A jej záverečným akordom A dur. Vykryštalizovanie Albrechtovej hudobnej reči sa naplno prejavuje práve v tejto kompozícii. Švorčastová klavírna suita je dielo, v ktorom sa odráža Albrechtovo kompozične vyspelé a vel'mi premyslené hudobné myslenie. V kompozícii sa upúšța od tóninového predznamenania, čím skladatel' upúšta od tonálneho ukotvenia. Nevykazuje náznaky poetickosti, intímnosti a emocionálnej híbky romantického ideálu, ako tomu bolo v klavírnej sonáte, ba naopak, nesie sa v duchu racionálneho myslenia s dôrazom na intelektuálnu zložku. V skladobnom riešení i samotnom zvuku môžeme postrehnút’ živelnost', Albrechtov optimistický a vecný náhl'ad s určitou dávkou sarkazmu a irónie. Kladie sa dôraz na rytmus a detailnú prácu s motívom, ktorý predurčuje zmenu charakteru. Skladatel' dáva vel'ký dôraz na motivicko-tematickú prácu, na ktorej je postavená celá kompozícia, nevyhýbajúc sa na niektorých miestach ani mikrotektonike. Vd’aka častému využívaniu chromatizmov, paralelizmov, tritónových intervalových štruktúr ako i disonantných akordických súzvukov vzniká harmonicky nejasná tonálna kostra, ale nájdeme tu aj miesta s tonálne funkčnou vzt’ažnostou. Uvol'ňovanie durovo-molovej tonality sa približuje k hraniciam atonality, avšak bez jej prekročenia.

Aj napriek tomu, že klavírne dielo netvorí hlavnú oblast’ Albrechtovho kompozičného odkazu, je jeho neoddelitel'nou súčast’ou. O to viac si zaslúži pozornost', či už zo strany interpretov, muzikológov, všetkých priaznivcov hudby, pričom v slovenskej klavírnej literatúre zastáva významnú pozíciu.

\section{POZNÁMKY}

1 CHALUPKA, Ĺubomír: Cestami k tvorivej profesionalite: Sprievodca slovenskou hudbou 20. storočia I. (1901 - 1950) Bratislava: Filozofická fakulta Univerzity Komenského, 2008, s. 30, s. 112.

2 KLINDA, Ferdinand: Alexander Albrecht. Bratislava: Slovenské vydavatel'stvo krásnej literatúry, 1959, s. 122.
Tamtiež, s. 124.

ALBRECHT, Alexander: Túžby a spomienky. Bratislava: Hudobné centrum, 2008, s. 115. 5 Tamtiež, s. 30.

\section{PRAMENE}

ALBRECHT, Alexander: Suita pre klavír. [Partitúra.] Bratislava: Hudobný fond, 2017, 40 s. ISMN 979-0-68500-329-8.

[Vo vytlačenej partitúre sa vyskytujú chyby (odchýlky od rukopisu), ktoré sme v našich príkladoch opravili podla korektúry klaviristky Daniely Varínskej.] 
SUMMARY

Alexander Albrecht - The Piano Suite

The contribution focuses on a piano piece which, despite its considerable compositional quality, is not frequently presented on Slovak concert stages. The study offers a detailed view on the Piano Suite through analysis of its particular movements - Dance, Humoresque, Lullaby, March - framed with an opening and closing commentary. In this work Alexander Albrecht turns away from impressionistic and neoromantic tendencies and proffers it with a distinctive artistic utterance which at the time - in 1924 - was a pioneering feat.

With the help of music analysis we pointed to the composer's compositional principles, piano stylization and musical language distinctive for this particular piece. We took the opportunity to observe its form, harmonic principles, motivic-thematic work and music expression of its respective movements. This "modern" suite reveals a rich source of composer's inspirations by progressive compositional devices noticeable in each of its movements - tritone chords, usage of unconventional intervals etc. Each movement abounds with its own peculiar ideas, mood, originality in the tangle of rich inventiveness.

Albrecht's Piano Suite has been recorded by two Slovak pianists - Daniela Varínska and Magdaléna Bajuszová. We believe that the music analysis offered by the study will contribute to the endeavour to revive and preserve the heritage of the Slovak music.

\section{Keywords}

Alexander Albrecht; piano music; Piano Suite 